\title{
Teachers' Perceptions of Developing Writing Skills in the EFL Classroom
}

\begin{abstract}
Despite the fact that English is taught as a foreign language in schools from an early age, students often face difficulties when it comes to the development of their writing skills. This paper aims at exploring teachers' perceptions regarding the development of the writing skills of elementary and secondary school EFL learners. Altogether, 85 Kosovar teachers were included in the survey. Even though the teachers believe that writing is important, they do not give the same emphasis to developing it as to other skills. According to their responses, some common difficulties learners experience while writing are a lack of vocabulary, writing anxiety, lack of ideas, mother tongue interference, grammar difficulties, weak structure organization and poor spelling. The teachers suggest that these difficulties might stem from a lack of reading and writing practice, ineffective teaching methods and low motivation for writing. We recommend various actions, such as teacher development courses to help them acquire more effective strategies of teaching writing, increased writing practice in the classroom, and the use of different learning strategies to meet all students' needs.
\end{abstract}

Keywords: teachers' perceptions; writing skills; EFL students; learning strategies

\section{Stališča učiteljev do razvijanja pisne zmožnosti pri pouku angleščine kot tujega jezika}

\section{POVZETEK}

Kljub dejstvu, da se angleščino poučuje že od začetka osnovne šole, se učenci še vedno soočajo $s$ težavami pri razvijanju pisne zmožnosti. $V$ prispevku raziskujemo stališča učiteljev do razvijanja pisne zmožnosti v angleščini osnovnošolskih in srednješolskih učencev. $V$ raziskavi je sodelovalo 85 učiteljev s Kosova. Verjamejo, da je pisanje pomembno, a temu ne posvečajo toliko pozornosti kot razvijanju drugih zmožnosti. Ugotavljajo, da se njihovi učenci pri pisanju soočajo s težavami, kot so pomanjkanje besedišča, strah pred pisanjem, pomanjkanje idej za pisanje, medjezikovna interferenca, slovnične napake, slabša struktura pisnega izdelka in pravopisne napake. Učitelji menijo, da prihaja do teh napak, ker učenci premalo berejo in pišejo, zaradi neučinkovitih metod poučevanja ter zaradi slabše motivacije za pisanje. Za izboljšanje stanja priporočamo seminarje za učitelje, na katerih bodo spoznali učinkovitejše strategije za poučevanje pisanja, več vaj za razvijanje pisne zmožnosti med poukom in uporabo različnih učnih strategij, ki bodo upoštevale različne potrebe učencev.

Ključne besede: stališča učiteljev; pisna zmožnost; učenci angleščine kot tujega jezika; učne strategije 


\section{Introduction}

Writing is considered one of the essential language skills that needs to be developed for successful communication. Moreover, it needs to be developed effectively in English as a foreign language (henceforth EFL), since English is used as a global academic language (Rahman 2002; Mansoor 2005; Marlina and Giri 2014; Mahboob 2014). Many authors have noted the common misconception that writing is simply a graphic representation of the spoken language. Hirvela and Belcher (2007) state that writing needs more planning while speaking is more highly contextualized. Johns (1990) argues that writing is not easy because writers are required to create and produce texts using significant discourse components. To produce a coherent and fluent piece of writing readers have to understand it without the possibility of asking for explanation or without seeing the writer's facial expressions or hearing the tone of their voice (Nunan 1999). Javid and Umer (2014) note that students' academic progress is often evaluated through writing, and so the evaluation of their overall language competence often depends on the level of their writing skills (Fageeh 2011). Furthermore, more communication is performed in writing nowadays due to advances in technology and the use of social media (Storch 2018).

EFL students are expected to produce logical, cohesive, clearly structured and wellorganized texts (Jacobs 1981; Hall 1988), but such writing requires accurate language use and a deep understanding of the language. However, English is not a transparent language, and learners often have difficulties because of the discrepancies between the sounds and letters (Cook 2016). Moreover, foreign language writers face difficulties because of the language transfer from their first language (Schoonen et al. 2009). A study conducted by Hisbullah (1994) reveals that patterns of the first language (in this case, Arabic) interfere significantly with regard to the syntactic errors made in the target language (English).

According to Hedge (2005), writing itself is not motivating enough for English learners to practice it regularly. Few people feel comfortable while writing a task intended to be judged by someone else, in particular when that "someone else" is a teacher (Hamp-Lyon and Heasly 2006).

Kroll (1990) claims that teachers play an essential role in helping students develop their writing skills, and should therefore consider some important points in making a course plan for developing writing skills. This begins with allocating time for a writing section, presenting aspects of the composition process, helping students with the use of grammar, determining the students' score in writing and also working on techniques that can help them improve. In addition, Harmer (2004) points out that teachers should focus on either the process of writing or the product of writing before designing a writing task. The process of writing involves five steps: pre-writing, writing, revising, editing and sharing the written work. In terms of the written production in a learning context, four steps are involved: the model text, controlled practice, organizing ideas and final product (Kamrul and Moniruzzaman 2010). The role of the teacher is significant in this process, since they guide students towards an effective writing achievement. According to Harmer (2007), the teacher has three roles in the classroom. First, the teacher plays the role of the motivator by providing opportunities to help students generate their ideas, encouraging 
them by using different techniques for writing. Secondly, the teacher acts as a resource, either offering help to learners in the writing process or guiding them in using the other resources available. The third role is the teacher as a feedback provider, giving effective feedback to students.

According to Noe (2004), there is a correlation between our perceptions and practice. Thus, teachers' perceptions influence their performance in teaching. If teachers perceive that writing in a foreign language is not as important as grammar, listening, vocabulary, speaking and reading, then this perception can influence their teaching of this skill (Ferede, Melese, and Tefera 2012). Consequently, if English language teachers do not pay attention to developing writing with their students, their performance in this skill will lag behind.

\section{The Study}

The present study addresses the issue of teachers' perceptions concerning developing learners' English language writing skills in primary school (1-9 grades) and secondary school (10-12 grades), and attempts to provide answers to the following research questions (RQ):

RQ1: How do English language teachers perceive writing as a language skill?

RQ2: How do students feel about writing in English, according to their teachers' perceptions?

RQ3: How do English teachers teach EFL writing in primary and secondary school?

RQ4: What strategies do teachers suggest for learners who have difficulties in developing writing skills?

RQ5: Are there any differences in novice and experienced teachers' perceptions of developing writing skills?

RQ6: Are there any differences in teachers' perceptions related to the grade they teach?

RQ7: Are there any differences in teachers' perceptions related to their gender?

RQ8: Are there any differences in teachers' perceptions related to their educational degree?

\subsection{Participants}

A total of 85 English language teachers were selected through systematic random sampling to participate in this study, all of whom are based in Kosovo. Among the 85 teachers selected, $70(82.3 \%)$ were females. The median years of teaching experience was three (one-24) years. Most of the teachers, 58 (68.3\%) had a bachelor's degree, 24 (28.2\%) had a master's degree, and three $(3.5 \%)$ had a doctoral degree (Table 1). Teachers with a bachelor's degree (68.3\%) worked in primary schools, whereas teachers with master's and doctoral degree $(31.7 \%)$ worked in secondary schools. 
TABLE 1. Participants' background information.

\begin{tabular}{|l|l|c|c|}
\hline & & Number & $\%$ \\
\hline \multirow{3}{*}{ Gender } & Female & 70 & 82.3 \\
\cline { 2 - 4 } & Male & 15 & 17.6 \\
\hline \multirow{2}{*}{$\begin{array}{l}\text { Educational } \\
\text { Background }\end{array}$} & Bachelor & 58 & 68.3 \\
\cline { 2 - 4 } & Master & 24 & 28.2 \\
\cline { 2 - 4 } & PhD & 3 & 3.5 \\
\hline
\end{tabular}

\subsection{Research Methods}

The data were collected in November 2018. For the purpose of the study, a questionnaire was developed with the aim of addressing the research questions listed above. The questionnaire included 12 questions and statements. The questions were grouped into categories which were used to examine the first four research questions (Table 2). The first group of questions was aimed at finding out how the English language teachers perceive writing as a language skill (questions 1 and 2). The second group of questions were aimed at understanding teachers' perceptions of how their students feel about writing in English (questions 3, 4, 5, 6). Understanding how the English teachers approach the teaching of writing was the aim of the third group of questions (questions 7, 8 and 9).

For the first three RQs, a five-point Likert scale was used to rate the degree of agreement with a statement (strongly agree, agree, undecided, disagree, strongly disagree). The fourth group of questions was designed with options to choose from as well as the opportunity to give open answers in order to find out what strategies would help students who have difficulties in writing in English, according to the teachers.

Furthermore, during the statistical analyses we tried to find out if there was a difference in teachers' perceptions regarding their teaching experience, the grades they teach, their gender and educational degree. These were examined using the second four research questions (RQ5, RQ6, RQ7 and RQ8).

The content validity of the questionnaire was confirmed by a panel of three experts who agreed that the questions and statements were aligned with the research questions. To test the questionnaire's reliability, the retest method was used. The same questionnaire was given to 18 teachers participating in the study who were randomly selected a month later. The similarity between the answers given on both occasions was statistically tested. The results did not show any statistical differences between the first and second tests $(\mathrm{p}=0.67)$, supporting the reliability of the questionnaire.

The data was statistically analysed and presented as the mean (standard deviation) when normally distributed or as the median (range) if not normally distributed. The Chi Square statistic was used to test the relationships between categorical variables. 
TABLE 2. List of statements and questions in the questionnaire used in the study.

\begin{tabular}{|c|c|}
\hline 1 & Writing is the most important language skill in the English language. (RQ1) \\
\hline 2 & Writing is the most difficult language skill in the English language. (RQ1) \\
\hline 3 & Students feel good when they have a writing task. (RQ2) \\
\hline 4 & Students feel frustrated while writing in English. (RQ2) \\
\hline 5 & $\begin{array}{l}\text { Students make more mistakes in writing in English than in speaking and reading. } \\
\text { (RQ2) }\end{array}$ \\
\hline 6 & Students have different preferences while writing in English. (RQ2) \\
\hline 7 & I give the same writing task to every student in the classroom. (RQ3) \\
\hline 8 & Writing is the language skill I find the most difficult to teach. (RQ3) \\
\hline 9 & $\begin{array}{l}\text { I dedicate the same amount of time to developing writing skills as I do to reading, } \\
\text { speaking and listening skills. (RQ3) }\end{array}$ \\
\hline 10 & $\begin{array}{l}\text { What general difficulties do you think students experience while writing in } \\
\text { English? (RQ4) }\end{array}$ \\
\hline 11 & Students face writing difficulties because of... (RQ4) \\
\hline 12 & What should be done in this regard? (RQ4) \\
\hline
\end{tabular}

\section{Results}

The results are presented below according to the main research questions.

\section{RQ1: How do English language teachers perceive writing as a skill?}

The results obtained from the analysis of the first two questions in the questionnaire were used to answer RQ1.

Figure 1 shows that $52.9 \%$ of the participants agreed and $11.7 \%$ strongly agreed that writing is the most important skill in the English language. Moreover, we can notice that most of the teachers perceived writing as the most difficult skill in the English language. These findings illustrate the awareness of the teachers that writing is an essential language skill.
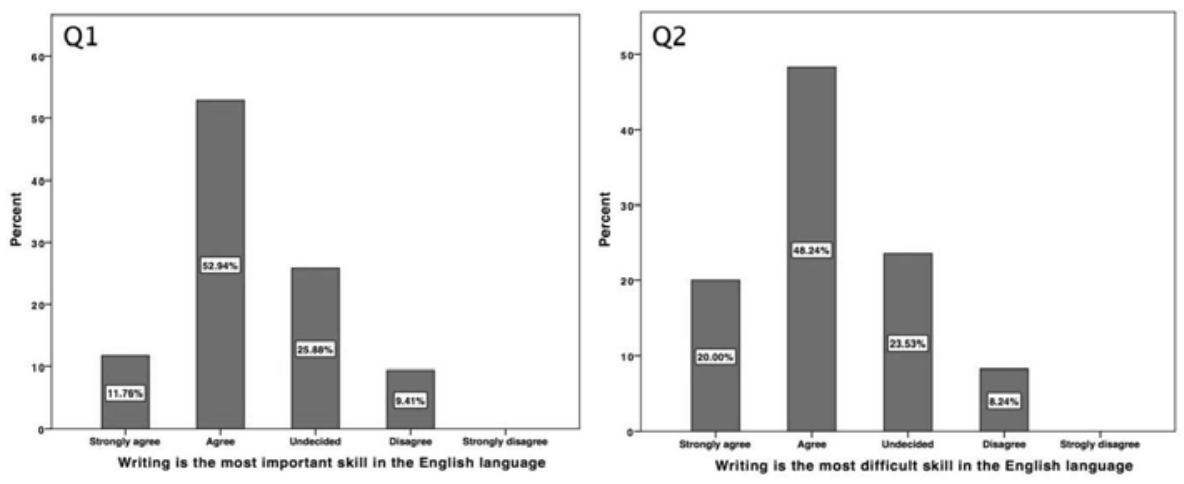

FIGURE 1. RQ1: How do English language teachers perceive writing as a language skill? 


\section{RQ2: How do students feel about writing in English?}

To answer this question, the results obtained from the analysis of questions 3, 4, 5 and 6 in Table 2 were used.

The teachers agreed that most students do not feel motivated when they have to write, and even feel frustrated when given writing assignments (Figure 2, Q3 and Q4). Since motivation is a crucial factor in learning, these findings are of a considerable concern. Furthermore, $44.7 \%$ and $35.3 \%$ of the teachers strongly agreed or agreed, respectively, that primary and secondary school students make fewer mistakes in speaking and reading than in writing (Figure 2, Q5). Moreover, most of the teachers (94\%) agreed or strongly agreed that there are different preferences among students when given writing assignments (Figure 2, Q6). To better understand the results of RQ2 we need to take a look at the results of RQ3.
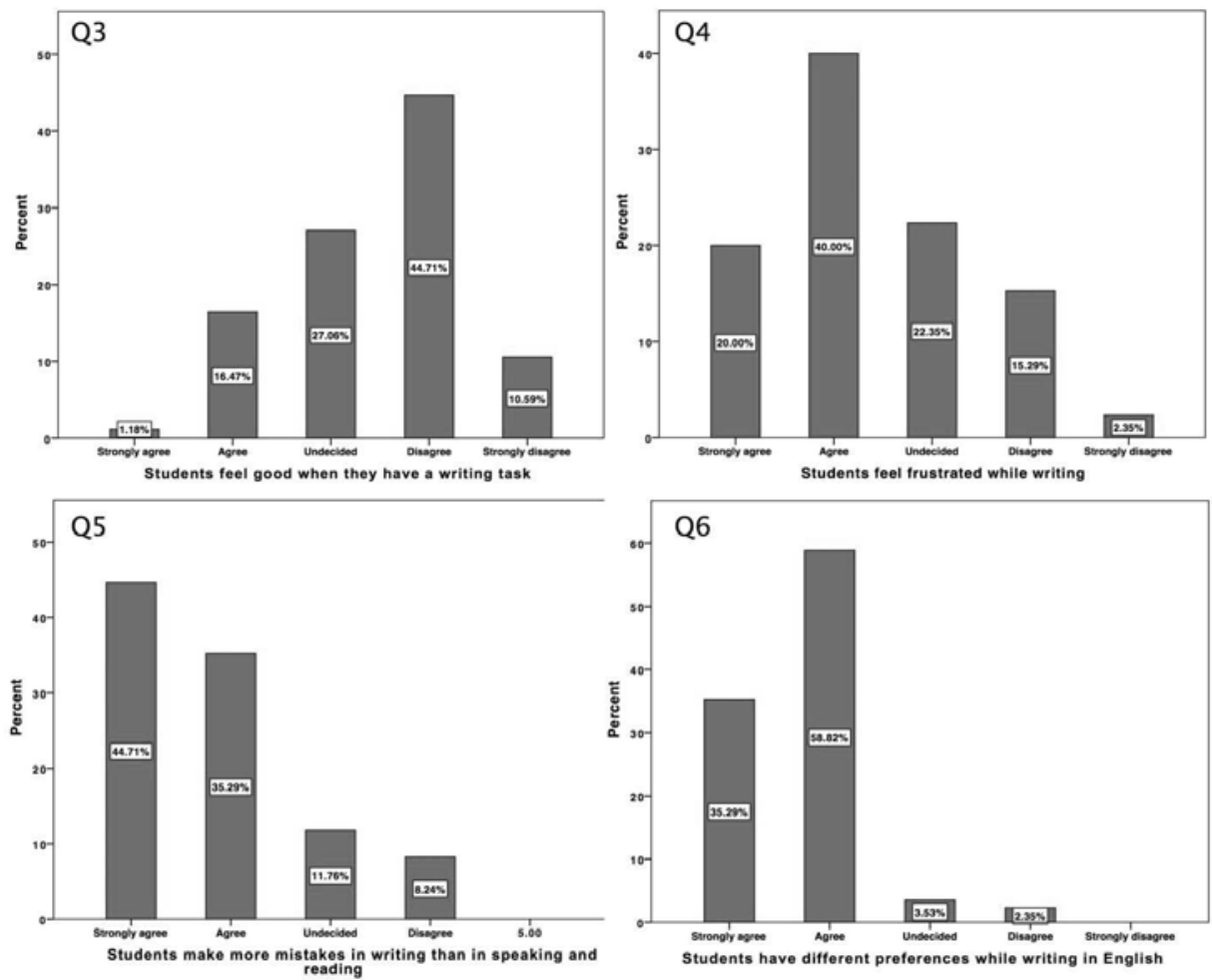

FiguRE 2. RQ2: How do students feel about writing in English, according to their teachers?

\section{RQ3: How do English teachers teach writing?}

The answer to this question was constructed from the analysis of questions 7, 8 and 9 in Table 2.

Almost half of the teachers (49.4\%) disagreed when asked if they dedicated the same amount of time to writing as to the other language skills (Figure 3, Q9). Moreover, the teachers mostly $(60 \%)$ gave the same writing task to every student, although they were aware of different preferences among them (Figure 3, Q7 and Figure 2, Q6). Finally, we can assume 
that this might be the case because $12.9 \%$ of them strongly agreed and $51.7 \%$ of them agreed that writing is the most difficult skill to teach (Figure 3, Q8).
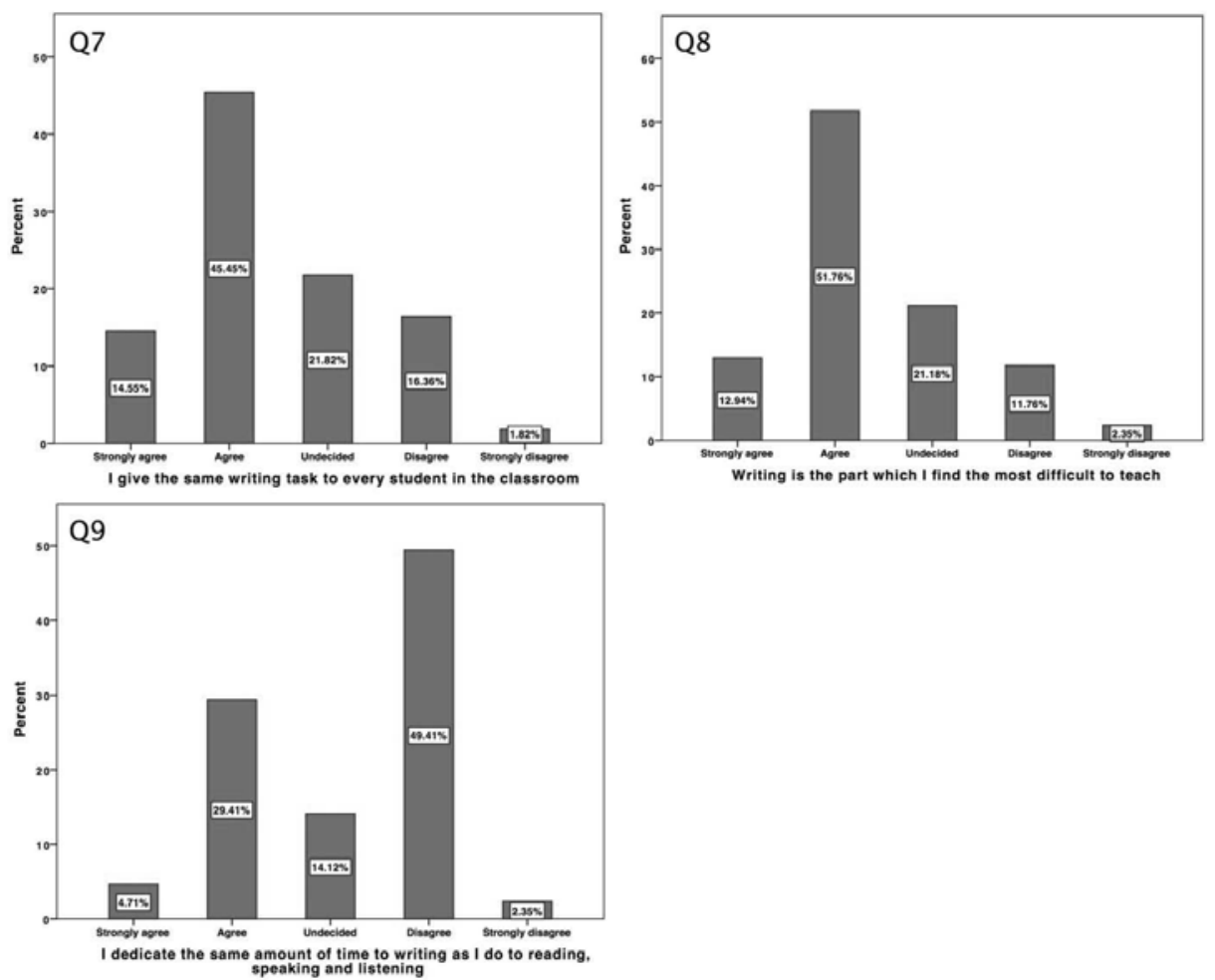

FIGURE 3. RQ3: How do English teachers teach EFL writing in primary and secondary school? RQ4: What strategies do teachers suggest for learners who have difficulties in developing writing skills?

The results obtained from the analysis of questions 10,11 and 12 in Table 2 were used to answer RQ4. As stated above, beside the options given in the questionnaire the participants were allowed to answer the question in open text format, but none of them selected it.

The teachers' responses show that students experience various difficulties while writing in English, mostly because of a lack of vocabulary (29.4\%), followed by writing anxiety $(18.8 \%)$, lack of ideas $(16.5 \%)$, reliance on mother tongue $(12.9 \%)$, grammar difficulties $(9.4 \%)$, weak structure organization $(8,2 \%)$ and poor spelling (4.7\%) (Figure 4, Q10). According to the teachers, these difficulties occur because of a lack of reading and writing practice $(50.6 \%)$, ineffective teaching methods (25.9\%), low motivation (14.1\%) and lack of ideas (9.4\%). Oddly enough, none of the teachers thought that having a large number of students in class is a problem (Figure 4, Q11).

When asked the most important question ('What should be done in this regard?'), the teachers responded as follows (Figure 4, Q12): 
- Differentiated instruction should be used to meet individual student needs (38.8\%).

- Schools should organize teacher development courses to help teachers learn new strategies about teaching writing (30.6\%).

- Different strategies should be used to motivate students to write (17.6\%).

- More time should be dedicated to writing tasks in a classroom (12.9\%).
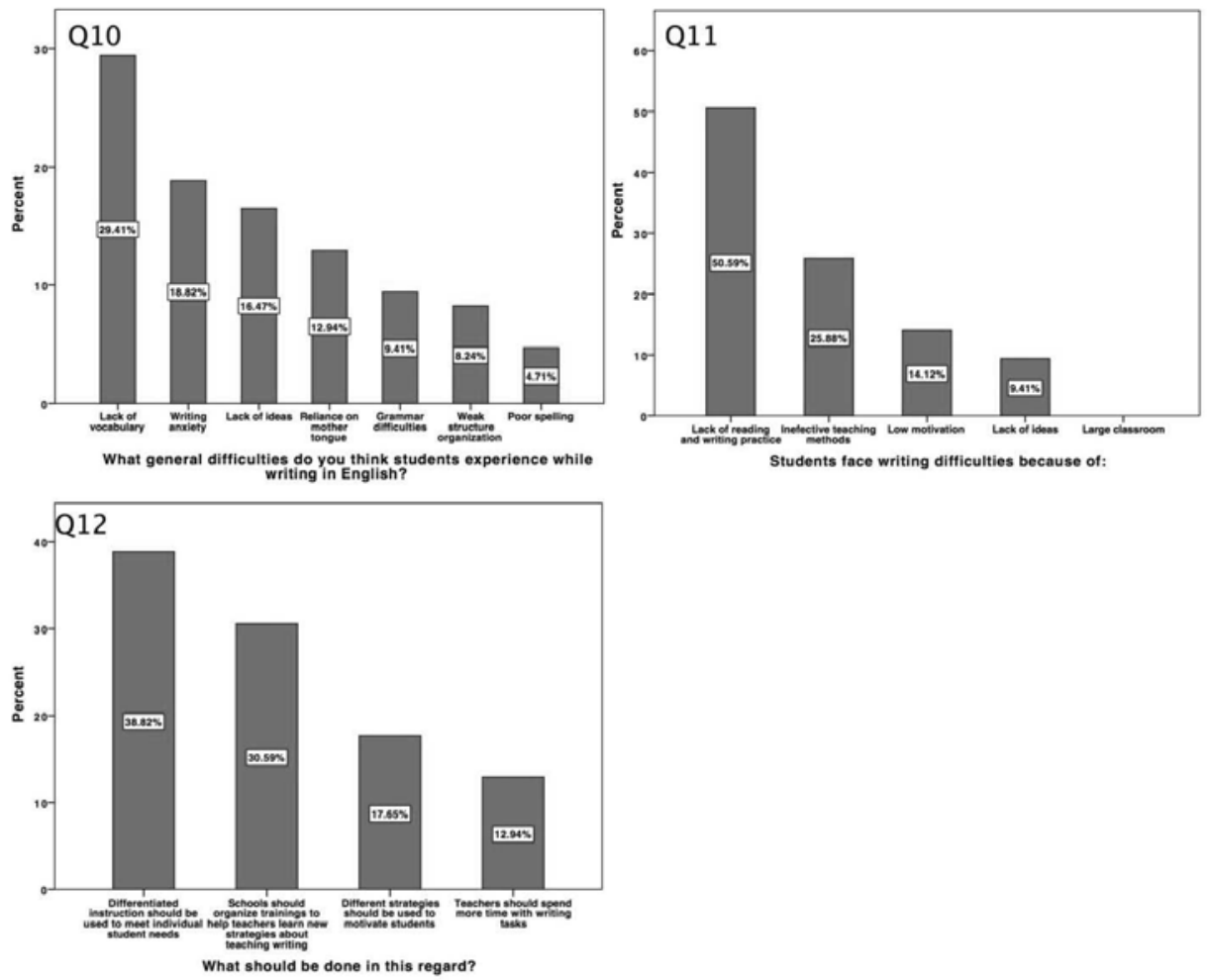

FiguRE 4. RQ4: What strategies do teachers suggest for learners who have difficulties in developing writing skills?

RQ5: Are there any differences in novice and experienced teachers' perceptions of developing writing skills?

Comparing the perceptions between teachers with less and more than five years of teaching experience, we did not find any significant differences in their views on developing writing except for the tenth question. Teachers with less experience presumed that students have difficulties in writing due to a lack of vocabulary $(31 \%)$, writing anxiety or lack of ideas $(22.4 \%$ and $20.7 \%$, respectively), while teachers with more experience were more heterogeneous in their opinions, 33.3\% thought that reliance on mother's tongue is the reason, while $25.9 \%$ that a lack of vocabulary is the reason behind students' difficulties in writing, $\mathrm{p}=0.012$ (Figure 5). 


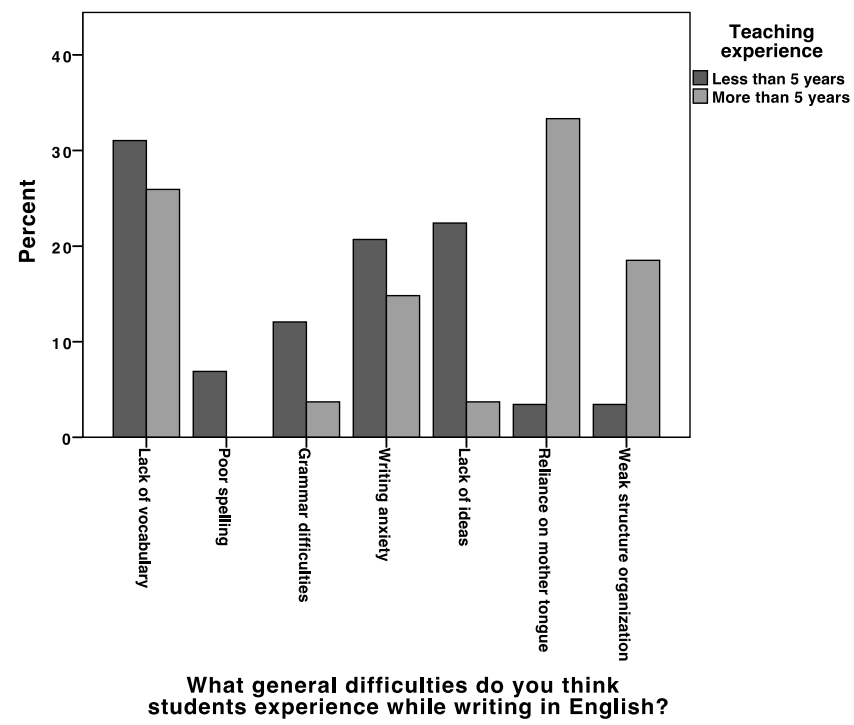

Figure 5. Differences in novice and experienced teachers' perceptions of students' difficulties in writing.

RQ6: Are there any differences in teachers' perceptions of developing writing skills related to the grade they teach?

Significant differences were found in the eighth question when comparing perceptions related to the grades that teachers taught $(\mathrm{p}=0.014)$ (Figure 6). More teachers who taught grades 6-9 agreed that writing is the most difficult skill to teach compared to teachers who taught grades $1-5$ and $10-12$. No other significant differences were found regarding other questions.

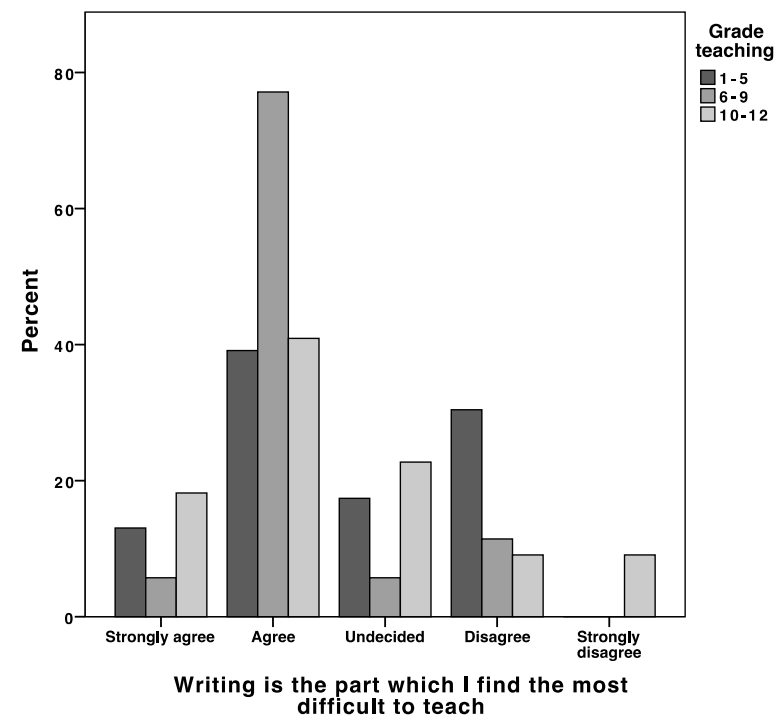

FiguRE 6. Differences in teachers' perceptions of developing writing skills related to the grades they teach. 
RQ7: Are there any differences in teachers' perceptions of developing writing skills related to their gender?

There were no significant differences between male and female teachers' perceptions regarding the developing of writing skills.

RQ8: Are there any differences in teachers' perceptions of developing writing skills related to their educational degree?

Similar to the above research question, there were no differences found in teachers' perceptions among the groups with different educational degrees.

\section{Discussion}

In this section the results are interpreted and discussed in relation to the research questions, and the findings are compared to those of previous research. Furthermore, the implications of the results are discussed.

RQ1 showed that teachers perceive writing as the most difficult and at the same time most important skill in the English language. Similar to our study, Darwish (2016) in the work entitled "Teachers' attitudes and techniques towards EFL Writing in Egyptian Secondary Schools", which included 44 teachers and 24 students, found that the teachers perceived writing as a difficult skill to teach. Moreover, in a study conducted by Ferede, Melese, and Tefera (2012), teachers agreed on the importance of writing as a skill, but contrary to our findings they believed that teaching writing was not more difficult than teaching speaking, listening or reading.

Regarding our results for RQ2, about how students feel about writing in English, based on their teachers' perceptions, other researchers have reported similar findings. For example, Friatin (2018) observes that most of the students in her study had less interest in writing in a foreign language, because of the difficulties they faced. Her research also shows that the students had difficulties in organizing their ideas and sentences, and that insufficient knowledge of language components, such as vocabulary and grammar, might be the underlying reason for this (Friatin 2018). Thus, the difficulty of learning how to write might be the reason behind frustration and lack of motivation in this context.

The results of RQ3 revealed that teachers spend less time on developing their students' writing competence compared to other skills. Correspondingly, other studies have found that teachers do not give sufficient focus to writing. Ferede, Melese, and Tefera (2012), report that English language teachers focused more on the development of speaking skills. Similarly, Cando-Guanoluisa, Campaña-Pallasco, and Panchi-Herrera (2017) report that writing was not practiced regularly in the classroom.

Moreover, we found out that teachers give the same writing task to every student, even while being aware of learning differences amongst them. Differentiated instruction is one of the strategies that can be used to meet all the students' needs. This is crucial because not everyone learns and writes at the same rate or at the same level. Every student has their own preferences related either to their interests, learning styles or language competence, to name just a few sources of differences (Tomlinson 2017). 
Koross, Indoshi and Okwach (2013) obtain similar results in a study about teachers and students' perceptions of the methods used by the teachers in teaching writing. They find that both teachers and students had negative perceptions of the methods that were applied in the writing class. They go on to state that this might be the reason behind the poor results in writing classes, and thus teachers need to adopt more effective methods when teaching writing that consider the students' needs and interests.

Other studies reveal that teachers do not differentiate writing tasks in the classroom. In a survey including fifty-eight tenth graders, Cando-Guanoluisa, Campaña-Pallasco, and Panchi-Herrera (2017) find that the writing classes they examined lacked an appropriate process of writing practice. The students were not taught strategies that would help them to organize their ideas, and most of the teachers put the main emphasis on vocabulary and grammar when teaching English (Cando-Guanoluisa, Campaña-Pallasco, and PanchiHerrera 2017; Ferede, Melese, and Tefera 2012). Koross, Indoshi, and Okwach (2013) recommend that teachers should be more flexible, developing teaching techniques based on the students' interests and needs. This is in accordance with teachers' suggestions on what strategies to use with students who have difficulties in developing writing skills, where most of the teachers think that different forms of instruction would help students improve their writing skills. A teacher can create a successful class that will allow all the students to be engaged by giving a writing assignment that has different levels of difficulty: for example, level one students can fill in the blank spaces in a text; level two students can write with the help of the guidelines, whereas level three students can write a text on their own. The teachers can also vary the amount of time needed to complete the writing assignment, they can request different alternatives related to the writing product from the students, and the writing process can be taught by the teacher in different ways, all according to the students' needs.

Different studies have shown the importance of using various strategies when teaching writing. Harmer (2004) suggests that different types of instructional media, e.g. audio and video materials, can be used by the teachers to explain language meaning and construction. Websites and social media play an important role in learning English. Many websites are designed especially for the purpose of learning writing, while social networks, such as online communities where people can share their ideas, interests and activities through the chat and messaging functions, either individually, in pairs or in groups, can be employed successfully in teaching writing to students. This has been shown in numerous recent studies (Friatin 2018; Jothi, Neelamalar, and Prasad 2011; Yunus, Salehi, and Chenzi 2012; Ping and Maniam 2015; Bani-Hani, Al-Sobh, and Abu-Melhim 2014).

Shehadeh (2011) looks into the efficacy of collaborative writing in second language classroom. The study included 38 first-year students at a university in the United Arab Emirates. In the control group writing tasks were carried out individually, while in the experimental group they were done in pairs. The results showed that collaborative writing helped the students to progress significantly in writing English, especially in terms of content, organization and vocabulary. The strategies presented in this work proved helpful not only for practical purposes, but also for motivational reasons (Shehadeh 2011). 
In accordance with the studies mentioned above, the teachers in our survey agreed that different strategies, such as differentiated instruction, should be used in class, but they were aware that they needed further support to learn new techniques in order to develop their students' writing skills.

The results of the fifth research question show that the perceptions of the teachers regarding the difficulties that students face while writing differ between teachers with less and more than five years of teaching experience. Moreover, the results show that teachers of grades 6-9 expressed a higher level of agreement with the statement that writing is the most difficult skill to teach, compared to those teaching other grades. Writing assignments are usually given more importance during this period, which might be the reason for this result. We did not find any differences between teachers' perceptions of developing writing skills when compared by gender or educational degree, which indicates that teachers have similar perceptions regarding the development of their students' writing skills regardless of their gender and degree of education.

\section{Conclusion and Recommendations}

This study set out to evaluate English language teachers' perceptions regarding the writing skills of primary and secondary foreign language learners in Kosovo. It found that the teachers perceive writing as the most important and difficult skill to acquire in language learning. Moreover, the teachers are aware that their students are not motivated to write in English. As such, the teachers give little attention to writing in class, and put more emphasis on the development of the other language skills. Likewise, the teachers do not differentiate writing tasks for their students. The fact that they view writing as just as significant as the other skills shows that the problem does not lie with the teachers perceptions regarding the importance of these skills, but with the way writing is taught. It might be said that Kosovar teachers fail to practice what they believe in. In future studies it would be interesting to research teachers' perceptions of developing writing skills in other European countries, as well as investigate the reasons behind the lack of writing practice in language classrooms through more indepth teacher interviews. Similarly, it would be beneficial to conduct classroom observations regarding the development of writing, and to find some examples of good writing practice.

Based on the teachers' responses of why learning and teaching writing in the English language are difficult, and the conclusions drawn from them, the following recommendations are made for practitioners.

a) It is important that English language teachers give equivalent emphasis to writing as they do to other skills, since writing is an essential language skill, especially in these days of greater technology use and the need to write more often.

b) Educational institutions need to focus on helping teachers to develop their teaching skills, especially different strategies to teach writing and how to motivate students to write in a foreign language. Differentiated instruction is one of the strategies that can be adapted to suit all students, since writing assignments can be differentiated by content, process and product. 
c) The use of technology in teaching writing is also a great opportunity to motivate students by showing them that writing can be a pleasant process and that following such steps can improve their writing skills.

Finally, it may be concluded that only by empowering teachers to use modern technology in their teaching and apply differentiated forms of writing instruction can we be sure that their students will become successful writers in a foreign language, and use this skill effectively in their professional and personal lives.

\section{References}

Bani-Hani, Nedal, Mahmoud Al-Sobh, and Abdel-Rahman Abu-Melhim. 2014. "Utilizing Facebook Groups in Teaching Writing: Jordanian EFL Students' Perceptions and Attitudes." International Journal of English Linguistics 4 (5): 27-34. https://doi.org/10.5539/ijel.v4n5p27.

Cando-Guanoluisa, Fabiola, Gissela Campaña-Pallasco, and Diana Panchi-Herrera. 2017. "Students' Perception about the Writing Instruction in English Classes." Dominio de las Ciencias 3 (4): 902-18.

Cook, Vivan. 2016. Second Language Learning and Language Teaching. 5th ed. London: Routledge.

Darwish, Hosam. 2016. "Teachers' Attitudes and Techniques Towards EFL Writing in Egyptian Secondary Schools." International Journal for 21st Century Education 3 (1): 37-57. https://doi.org /10.21071/ij21ce.v3i1.

Fageeh, Abdulaziz Ibrahim. 2011. “EFL Learners' Use of Blogging for Developing Writing Skills and Enhancing Attitudes Towards English Learning: An Exploratory Study." Journal of Language and Literature 2 (1): 31-48.

Ferede, Tekle, Endalfer Melese, and Ebabu Tefera. 2012. "A Descriptive Survey on Teachers' Perception of EFL Writing and Their Practice of Teaching Writing: Preparatory Schools in Jimma Zone in Focus." Ethiopian Journal of Education and Sciences 8 (1): 29-52.

Friatin, Lilies Youlia. 2018. "Students' Perception on Teaching Writing Through Facebook Group in EFL Class." Journal for Language and Foreign Language Learning 7 (1): 55-76. https:// doi.org/10.21580/vjv7i12739.

Hall, Donald. 1988. Writing Well. Boston: Little, Brown and Company.

Hamp-Lyon, Liz, and Ben Heasly. 2006. Study Writing. 2nd ed. Cambridge: Cambridge University Press. Harmer, Jeremy. 2004. How to Teach Writing. United Kingdom: Pearson Education Limited.

-. 2007. How to Teach English. United Kingdom: Pearson Education Limited.

Hedge, Tricia. 2005. Writing. Oxford: Oxford University Press.

Hirvela, Alan, and Diane Belcher. 2007. "Writing Scholars as Teacher Educators: Exploring Writing Teacher Education.” Journal of Second Language Writing 16 (3): 125-218.

Hisbullah, Abdullah. 1994. "Analysis of Syntactic Interference Errors in the Writing of English by Saudi Adult Students." PhD diss., Pennsylvania State University.

Jacobs, Holly L. 1981. Testing ESL Composition: A Practical Approach. English Composition Program. Massachusetts: Newbury House Publishers.

Javid, Choudhary-Zahid, and Muhammad Umer. 2014. “Saudi EFL Learners' Writing Problems: A Move Towards Solution." In Proceeding of the 2nd Global Summit on Education GSE, Kuala Lumpur, Malaysia, March 4-5, 2014, 164-180. Kajang: WorldConferences.net.

Johns, Ann M. 1990. "L1 Composition Theories: Implications for Developing Theories of L2 Composition." In Second Language Writing, edited by Barbara Kroll, 24-36. Cambridge: Cambridge University Press. https://doi.org/10.1017/CBO9781139524551.006.

Jothi, P. Sri, Maraimalai Neelamalar, and R. Shakthi Prasad. 2011. "Analysis of Social Networking Sites: A Study on Effective Communication Strategy in Developing Brand Communication." Journal of Media and Communication Studies 3 (7): 234-42. 
Kamrul, Hasan, and Akhand Moniruzzaman. 2010. "Approaches to Writing in EFL/ESL Context:

Balancing Product and Process in Writing Class at Tertiary Level.” Journal of NELTA 15 (1-2): 77-88.

Koross, Benjamin Towett, Francis C. Indoshi, and Tony Okwach. 2013. "Perception of Teachers and Students Towards Methods Used in Teaching and Learning of English Writing Skills in Secondary School." International Journal of English Language and Linguistics Research 1 (1): 32-38.

Kroll, Barbara. 1990. Second Language Writing: Research Insights for the Classroom. Cambridge: Cambridge University Press.

Mahboob, Ahmar. 2014. "Epilogue: Understanding Language Variation: Implications for EIL Pedagogy.” In The Pedagogy of English as an International Language: Perspectives from Scholars, Teachers, and Students, edited by Roby Marlina and Ram Ashish Giri, 257-65. Switzerland: Springer.

Mansoor, Sabiha. 2005. Language Planning in Higher Education: A Case Study of Pakistan. Karachi: Oxford University Press.

Marlina, Roby, and Ram Ashish Giri. 2014. The Pedagogy of English as an International Language: Perspectives from Scholars, Teachers, and Students. Vol. 1. Switzerland: Springer. https://doi.org/10.1007 1978-3-319-06127-6.

Noe, Alva. 2004. Action in Perception. Massachusetts: Massachusetts Institute of Technology Press.

Nunan, David. 1999. Second English Teaching and Learning. Boston: Heinle \& Heinle.

Ping, Ng Sau, and Mahendran Maniam. 2015. "The Effectiveness of Facebook Group Discussions on Writing Performance: A Study in Matriculation College." International Journal of Evaluation and Research in Education (IJERE) 4 (1): 30-37. https://doi.org/10.11591/ijere.v4i1.4489.

Rahman, Tariq. 2002. Language, Ideology and Power. Vol. 1. United Kingdom: Oxford University Press.

Schoonen, Rob, Patrick Snellings, Marie Stevenson, and Amos van Gelderen. 2009. "Towards a Blueprint of the Foreign Language Writer: The Linguistic and Cognitive Demands of Foreign Language Writing." In Writing in Foreign Language Contexts. Learning, Teaching, and Research, edited by Rosa M. Manchón, 77-101. Bristol: Multilingual Matters.

Shehadeh, Ali. 2011. "Effects and Student Perceptions of Collaborative Writing in L2." Journal of Second Language Writing 20 (4): 286-305. https://doi.org/10.1016/j.jslw.2011.05.010.

Storch, Noemy. 2018. "Learning Writing." In The Cambridge Guide to Learning English as a Second Language, edited by Anne Burns and Jack C. Richards, 222-30. Cambridge: Cambridge University Press.

Tomlinson, Carol Ann 2017. How to Differentiate Instruction in Academically Diverse Classrooms. 3rd ed. Alexandria: ASCD.

Yunus, Melor Md, Hadi Salehi, and Chen Chenzi. 2012. "Integrating Social Networking Tools into ESL Writing Classroom: Strengths and Weaknesses." English Language Teaching 5 (8): 42-48. https://doi .org/10.5539/elt.v5n8p42. 